\title{
Introduction
}

\section{Next-Generation Linkage Analysis}

\author{
Veronica J. Vieland ${ }^{\mathrm{a}}$ Marcella Devoto $^{\mathrm{b}}$ \\ a Battelle Center for Mathematical Medicine, The Research Institute at Nationwide Children's Hospital, and \\ Departments of Pediatrics and Statistics, The Ohio State University, Columbus, Ohio, and bivision of \\ Human Genetics, The Children's Hospital of Philadelphia, Department of Pediatrics, Perelman School of Medicine, \\ University of Pennsylvania, Philadelphia, Pa., USA
}

With the advent of affordable high-throughput genetic sequence, the human genetics community is returning to a focus on family data. Sequencing family members can facilitate data cleaning by identifying putative nonMendelizing variants. It can also provide a powerful mechanism for discerning the sequence variants most likely to be relevant, by focusing attention on those variants segregating with the phenotype of interest. By the same token, sequencing holds out the possibility of capitalizing on earlier gene localization findings based on analyses of family data - findings that have provided numerous tantalizing trait loci for a wide range of complex phenotypes, but to date have resulted in relatively few definitive identifications of specific causal genes within those loci.

Against this background it is not surprising to hear increasing talk of the utility of 'co-segregation' analysis, or, in classical statistical genetic parlance, linkage analysis. But what may not be widely appreciated is that the statistical and computational technologies available for linkage analysis have evolved considerably since the early days. Currently available methods now eclipse those of a decade ago in flexibility, power, and computational reach.
This special issue of Human Heredity is intended to showcase some of these advances. Following a review of classical linkage theory and approaches (Bailey-Wilson and Wilson), the remaining papers cover a variety of newer approaches to handling complex phenotypes in sophisticated ways, to performing computationally intensive linkage calculations, and to utilizing simulation to evaluate methods and assist in the interpretation of results. They also provide some alternative statistical frameworks, giving the flavor of what can be possible if we move beyond the conventional cataloguing of $p$ values to avail ourselves of state-of-the-art alternative paradigms under development within the field of mathematical statistics. Finally, they showcase some of the powerful new software programs available for this 'next generation' of linkage analysis approaches.

The set of methods presented in this issue is of course far from exhaustive. Many other excellent software packages and approaches exist beyond those covered here. But as the field returns to an appreciation of the power of linkage analysis, we hope that in aggregate the papers in this issue will convey the flavor of what is now possible.

\begin{tabular}{ll}
\hline KARGER & (c) 2011 S. Karger AG, Basel \\
0001-5652/11/0724-0227\$38.00/0 \\
$\begin{array}{l}\text { Fax +4161306 1234 } \\
\begin{array}{l}\text { E-Mail karger@karger.ch } \\
\text { www.karger.com }\end{array}\end{array}$ & $\begin{array}{l}\text { Accessible online at: } \\
\text { www.karger.com/hhe }\end{array}$
\end{tabular}

Veronica Vieland, Battelle Center for Mathematical Medicine The Research Institute at Nationwide Children's Hospital Departments of Pediatrics and Statistics, The Ohio State University Columbus, $\mathrm{OH} 43205$ (USA)

Tel. +1 614335 2861, E-Mail veronica.vieland@nationwidechildrens.org 